\title{
Stanisław Adamiak*
}

Pontifical Gregorian University

\author{
Ewa Chojnacka, Damian Walczak ${ }^{* *}$ \\ Nicolaus Copernicus University
}

\section{SOCIAL SECURITY IN POLAND \\ - CULTURAL, HISTORICAL AND ECONOMICAL ISSUES}

Keywords: social security system, Catholic social teaching, social solidarism.

Classification J E L: H55, H53, A13, E02.

\begin{abstract}
In the first place, the paper analyses the cultural-historical background of the social security in Poland. Given the largely enrooted Catholicism of the country, the development of the social teaching of the Catholic Church is surveyed. It is followed by a short history of the social security legislation in Poland from 1918 to 1997, and finally the current economical conditions of the system are analysed. The paper concludes with the opinion, that the current system, providing large social endowments to various strata of the population, generally answers the expectations of the people as well as corresponds to Catholic social teaching.
\end{abstract}

ZabezPIECZENiE SPOŁECZne W POLSCE

- UWARUNKOWANIA KULTUROWO-HISTORYCZNE ORAZ EKONOMICZNE

Słowa kluczowe: zabezpieczenie społeczne, katolicka myśl społeczna, solidarność społeczna.

Data wpłynięcia: 20.11.2013; data zaakceptowania: 20.12.2013.

* Dane kontaktowe: stasadam@o2.pl, Faculty of History and Cultural Heritage of the Church, Pontifical Gregorian University, Piazza della Pilotta 4, 00187 Rome.

** Dane kontaktowe: dwalczak@umk.pl, Katedra Zarządzania Finansami, Wydział Nauk Ekonomicznych i Zarządzania, Uniwersytet Mikołaja Kopernika w Toruniu, ul. Gagarina 13a, 87-100 Toruń, tel. 566114634. 
Klasyfikacja J E L: H55, H53, A13, E02.

\begin{abstract}
Abstrakt: Artykuł rozpoczyna analiza tła historyczno-kulturowego zjawisk związanych z zabezpieczeniem społecznym w Polsce. Ze względu na znaczącą rolę religii katolickiej w naszym kraju, przedmiotem opisu jest najpierw nauczanie społeczne Kościoła katolickiego dotyczące tej materii. Następnie przedstawiono skróconą historię prawodawstwa związanego z zabezpieczeniem społecznym w Polsce w okresie od 1918 do 1997 r. oraz analizę sytuacji obecnej. Przeprowadzona analiza wskazuje, że system zabezpieczenia społecznego w Polsce jest rozbudowany. Szeroki zakres świadczeń przeznaczonych dla różnych grup społecznych odpowiada zarówno ogólnym oczekiwaniom obywateli, jak i idei solidaryzmu społecznego wynikającej m.in. z katolickiej nauki Kościoła.
\end{abstract}

Translated by Ewa Chojnacka

\title{
IIINTRODUCTION
}

Every state is obliged to take care of its citizens. Depending on a state's current political system, government policies or financial situation, it differentiates the scope of social welfare provided to its citizens. Institutionalised forms of social security appeared in Europe relatively late - in the nineteenth century. Prior to the nineteenth century, various forms of social security had been provided by churches, orders, gentry, communes or by guilds.

The subject literature is abundant in definitions of social security, however, we may disregard them and approach and define the term lexically. 'Security' means protecting from something (for instance, from such occurrences as diseases, disabilities, poverty, or advanced old age) and the word 'social' indicates the reference to society both in terms of individual beneficiaries and in terms of common goals (social solidarism).

As regards the scope of benefits, taking into account the criterion of financing, social security comprises financial benefits (financed by persons insured), benefits received without prior payment of contributions (financed by the state) and philanthropic benefits (financed by external entities) ${ }^{1}$.

${ }^{1}$ When applying different criteria, further methods may be distinguished such as the following: the insurance method, the no-contribution method, and the caring method (more in Łyskawa 1999, 191-192). 


\section{RESEARCH METHODOLOGY AND THE COURSE OF THE RESEARCH PROCESS}

The process of shaping the right to social security benefits was impacted by economic, social, cultural, political and legal factors. The objective of the present paper is to outline historical, cultural and economic conditions of Poland's social security, particularly by applying a research method of critical analysis of literature. Using that method together with reviewing legal acts resulted in illustrating the roots of social security that stem from the Christian tradition. Also, the paper discusses the current social security benefits with the consideration of their degree of (self-)financing.

The literature concerning the subject matter is abundant, however, in general, it is thematically divided into groups of studies focused on history (Zieliński 1994; Aspalter, Jinsoo, Sojeung 2009; Fajth 1999), on the current legal and economic situation of social security (Koczur 2012; Garbiec 2008; Social Security... 2012; Walczak 2011), on philosophical basics of social solidarism (Rugina 1983) and on Catholic social teaching (Strzeszewski 1994; Chojnicka 2001; Backer 2010). The present paper adopts a cross sectional approach through a diachronic analysis and through an attempt to answer the question about the extent to which the current social policy corresponds to the Catholic background represented by the majority of the Polish society.

\section{SOCIAL SECURITY IN THE TEACHINGS OF THE CATHOLIC CHURCH}

When dealing with the issue of social solidarism, its past social and cultural background cannot be underestimated. In the case of Poland it is necessary to consider its deeply rooted Christian tradition, with the emphasis laid on the teachings of the Catholic Church. In particular, attention should be paid to the so-called Catholic social teaching that in the interwar period of the twentieth century played a remarkable role among the major political forces ${ }^{2}$ as well as to Christian-democratic parties that shaped the social and economic systems in post-war Europe.

The Bible, which lays foundations to Christian morality, clearly indicates the need to take care of the poor (especially those harshly experienced - or-

2 Article 114 of the Constitution from March 1921 says that: 'The Roman Catholic religion, being the religion of the preponderant majority of the nation, occupies in the state the chief position among enfranchised religions'. 
phans and widows) and to share material possessions with those who really need them. In the first Christian community founded in Jerusalem: 'All who believed were together and had all things in common; and they sold their possessions and goods and distributed them to all, as any had need' (Acts 2, 44-45). It must be noted, however, that this was an exceptional situation since other Christian communes, described by St. Paul in his letters, did not apply such 'community of possessions'.

Christians living in early centuries did not object the social and economic system of the Roman Empire but they used to run extensive charitable activities.

Julian the Apostate (361-363), was a Roman emperor who attempted to stop the development of Christianity and to restore the traditional religion in the empire, however, he was of the opinion that Christians' approach to and treatment of the poor was a pattern to be followed.

The call to share possessions did not exclude the sanctity of private property. Christian morality originates from the Decalogue, therefore, any offenses against property were regarded as a sin against the seventh commandment - 'thou shalt not steal'. In medieval times systematic approaches to morality were based on the reference to further virtues. The virtue of love demanded Christians to help their neighbours by getting rid of their material possessions. Monks were expected to practice this virtue heroically through making the vows of poverty and repudiating any of their material possessions. Actually, it remained an ideal only and very few were able to achieve it. As a matter of fact, at that time social relationships were regulated by the virtue of justice. It was considered righteous to provide everybody with what they lawfully deserved, so, consequently, there was no room for any form of 'social security' - this could come only from mercy. The exception was children's support given to their parents and that resulted from the obligation created when parents were taking care of them as well as from the fourth Commandment; hospitals, asylums, schools were treated in a similar way. Running them was the obligation of the church and of affluent citizens, however, it was a religious obligation and basically it did not correspond to the virtue of justice. It is worth reminding the doctrine of the so-called 'needless goods' (bona superflua), which says that any excess possessions belong to poor people by the virtue of justice; it is so because the virtue of justice concerns not only interchangeable justice (i.e., honest fulfilment of mutual obligations) but also distributive justice (i.e., a just distribution of goods). 
The doctrine of 'needless goods' was proclaimed by eminent theologians, including the most famous one, St. Thomas Aquinas (1225-1274) (Summa Theologiae, $\mathrm{II}^{\mathrm{a}}-\mathrm{II}{ }^{\mathrm{ae}}$, q. 66 , a. $7, \mathrm{sc}$ ), however, no major efforts were made to implement the doctrine since it was difficult to define precisely what 'excess goods' were (Strzeszewski 1960). Nevertheless, in 1959 Cardinal Stefan Wyszyński cited the doctrine asking the future Ecumenical Council to remind the affluent citizens about their obligations (Wyszyński 1959, 684).

Actually, what has been emphasised for centuries was the inviolability of property, which allows breaching it only in exceptional situations such as, for instance, immediate danger of death. At the beginning of the twentieth century St. Józef Sebastian Pelczar stressed that the poor cannot expect help by the virtue of justice - they should expect it only from mercy shown by rich people; in bishop Pelczar's view, the obligation to help should be ascribed to the family, next to the parish and in the end to the whole society. The state should be the last to provide such help. In the bishop's opinion 'a tax paid by the wealthy for the poor', despite some advantages, is morally dubious, since as a mandatory contribution it releases the rich from the obligation to give alms, makes the poor think that they have the right to make demands to society and does not guarantee that help will be given to those who need it most (Pelczar 1915, 233. 30-31).

This sceptical attitude of the Church to 'a tax paid by the wealthy for the poor' was partially justified by the multi-century agrarian social structure within which natural and basic social security was provided by a multigenerational family, therefore, there was no need for pensions, kindergartens and nurseries. Mercy shown by society concerned primarily those people who, for different reasons, were outside this basic family structure. The nineteenth century industrial revolution resulted in rapid urbanisation and in an increased working class which, in turn, led to the weakening of families and social ties, intensification of socialist and communist activities that demanded a new way of distributing goods and ultimate removal of private property. The relations between the groups of socialists and communists and the Church became hostile due to the atheistic views represented by the former and due to discrediting the already established social order and property rights which in the view of the Church resulted from the natural law. However, within the same Church we could observe an increasing awareness of social injustice resulting from the development of capitalism and that injustice could not be compensated even by extensive and far reaching philanthropic activities. The turning point was the publication of an encyclical titled 'Rerum novarum' (About New Things) by Pope 
Leo XIII in 1891. It is considered to be the foundation of modern Catholic social teaching, which urged believers to consider the problems of the working class and acknowledge the need of maintaining private property, however, they also stressed that the free market economic activity must be controlled by moral principles.

The Catholic social teaching have been developed by the subsequent popes who tried to encourage believers to base their social lives on moral principles and, in particular, on the principle of subsidiarity (Pius XI, Quadragesimo Anno, 5), on the principle of the concern for common good (John XXIII, Mater et Magistra, 65; John Paul II, Centesimus Annus, 47), and on the principle of solidarity (Jan Paweł II, Sollicitudo Rei Socialis, 40).

As the first of the above encyclicals objected statism and an excessive concentration of obligations and resources in the hands of the state (which followed the logics of socialism), the second and the third ones objected unfettered liberalism.

Christian-Democratic parties that ruled in many countries after the second world war followed the Catholic social teaching and as a result opted for building welfare states and were backed by left-wing parties in their endeavours. The principles of the Catholic social teaching were frequently referred to in Poland after 1989. These references included in multiple statements by politicians and clergymen were often purely declarative in nature. The Catholic social teaching was often understood as declarations made by the Church on controversial issues concerning morality, bioethics, and neutrality of a secular state $^{3}$. It must be underlined, however, that depending on the time period con-

${ }^{3}$ At present the issue of social solidarism in Poland is contained in the programmes of several political parties. A political grouping with the name that is meaningful in the context of the subject - Solidary Poland (Solidarna Polska), in its programme declaration uses the following formulation: 'social solidarity means that the state provides social security to the nation and shares tax burden equitably'. Law and Justice (the strongest opposition party) inserted the following formulation in its political programme: 'Solidary Poland is a country in which the fruit of the economic development shall be shared by poorer citizens and economically less developed regions, a country in which setting up a family and raising children shall be respected and supported by the state in which citizens are guaranteed adequate pensions and support in difficult situations. 'The Polish People's Party (a coalition party in the Polish government) in its resolution from the $11^{\text {th }}$ Congress held on 07 November, 2012 in a fragment concerning the formulation of its ideological programme declares that: 'the principles of our programme resulting from [...], formulated on the grounds of the principles of social market economy, humanitarianism, Christian ethics and the social teaching of the Catholic Church contrib- 
sidered the emphasis of the Catholic social teaching is shifted to different issues. The encyclical written in 1991 by Pope John Paul II Centesimus Annus ('The Hundredth Anniversary of Rerum Novarum') was the closest in its meaning to the affirmation of free-market capitalism, while Caritas in veritate ('Charity in Truth') issued by Pope Benedict XVI in 2009 is concerned primarily with the significance of solidarism understood also as a global phenomenon.

\section{THE BEGINNINGS OF SOCIAL SECURITY IN POLAND}

The development of Poland's system of social security at the end of the nineteenth century was conditioned by the historical and cultural situation (shaping the Catholic social teaching and the growth of socialist parties). After Poland regained its independence in 1918, the previously created legal and institutional solutions were used, however, the intensity of the use varied depending on the part of the country (the Prussian Partition could boast of the best developed social security system). Therefore, the interwar-period Poland realised simultaneous processes of the unification and adjustment of the legal basis for social security to the new socio-economic conditions.

Undertaking the above-mentioned activities was necessary. The first reason for undertaking those activities resulted from the fact that after the first world war society, as a whole, became significantly poorer and families lost their ability to fulfil some of their social security (welfare) functions. Secondly, the activities were related to the economic reconstruction of the country, the structural changes caused by the development of industry and the working class, and by the aforementioned role played by the Church in the country. As a result, within a relatively short time period of five years after regaining independence, the following regulations were introduced: on sickness insurance (1919-1920), on temporary support for the unemployed (1919), on unemployment insurance (1924), on accident insurance (1923) and on social welfare (1923).

ute to building a social system based on [...]: the principle of solidarism, [...] the principle of justice and social love. 'Polish prime minister Donald Tusk in his policy statement from 18 November 2011 said: 'we want under this and under other systems of financial support apply absolutely the method of social justice, solidarism of richer people with those who are in a worse situation'. A left-wing party Your Move does not make reference to the teaching of the Catholic Church, however, in its programme declaration it emphasises that the state should take care of those 'whom fate deprived of life chances and of health'. 
As regards social insurance, in 1927 insurance for white collar workers was introduced which manifested unfair social privileges possessed by that group, if compared with a group of physical workers. The latter group was covered by social insurance in 1933 by virtue of the act on social insurance referred to as the unifying act (Zieliński 1994, 43).

It must be noted that there existed additional separate regulations on social supplies to selected social groups, e.g., state officials and professional soldiers (1923), Polish Railways employees (1926 and 1929), former political prisoners (1931), or veterans of independence fights (1937). The reason for passing the special regulations was striving for providing security to honoured social groups due to the functions fulfilled by them in the country, their role in regaining independence, or due to performing work of special character.

The development of a social security system was stopped by the outbreak of the second world war. After the war, under an entirely new geopolitical situation, further legal regulations continued to be implemented. Due to the then political system (and to the official non-occurrence of unemployment), the regulations concerned primarily social insurances and were reflected in reaching new social groups, for instance, craftsmen (1965), artists (1973), individual framers (1977), clergymen (1989), as well as in extending the coverage (for example, by the introduction of family benefits). The intention was to eliminate selected privileged groups and work out a system of equal treatment of white collar and blue collar workers ${ }^{4}$.

\section{Social SECURITY SYSTEM IN POLAND - THE CURRENT STATE OF AFFAIRS}

The change of the political and economic system in 1989 necessitated reforms of the elements of social security and its adjustment to new circumstances within the country and in the international environment. The solutions presented in further parts of the paper and concerning social security in Poland are consonant with the Catholic social teachings that are contained also in the encyclicals written by Pius XI, John XXIII, and John Paul II. On the one hand, the good of a whole society is essential and an individual is obliged to support all people (due to social security benefits social stratification is mitigated), on the other

4 The purpose of the work is not to provide a thorough description of the changes and development of legal regulations concerning social insurance, but to indicate initial regulations within specific elements of security. The description of origins and development of social insurance prior to 1993 can be found in (Zieliński 1994). 
hand, however, an individual constitutes a goal and, therefore, has the right, within reasonable limits, to take care of his/her own good (e.g., pension dependent of the value of the assets saved by an individual).

Social security in Poland is defined by the Constitution of the Republic of Poland. Article 67 (1) of the Constitution says that: 'A citizen shall have the right to social security whenever incapacitated for work by reason of sickness or invalidism as well as having attained retirement age. The scope and forms of social security shall be specified by statute.' And further, Article 67 (2) says: 'A citizen who is involuntarily without work and has no other means of support, shall have the right to social security, the scope of which shall be specified by statute.'

The Act from 4 of September, 1997 on the Sections of Governmental Administration specifies the elements that shall be covered by social security treated as a separate section of governmental administration. It remains, however, unclear whether health care may be indicated as an element of social security. Due to the specificity of health care, the Act on the Sections of Governmental Administration regards it as a separate item but, since health care services are financed from social security contributions paid by all citizens regardless of their levels of income, undoubtedly it does constitute one of the elements of the social security system in Poland. Therefore, it may be stated that social security is comprised of the following:

- social insurance,

- personal and property insurances,

- health care,

- welfare services,

- complementary social benefits,

- rehabilitation of the disabled.

The major legal acts that regulate the elements of the social security system in Poland include the following:

1. The Act of 13 October 1998 on Social Insurance System (Journal of laws of 2009, no. 205, item 1585 with later amendments),

2. The Act of 17 December 1998 on Old-Age and Disability Pensions from the Social Insurance Fund (Journal of laws of 2009, no.153, item 1227 with later amendments),

3. The Act of 21 November 2008 on Capital Pensions (Journal of laws of 2008 , no. 228, item 1507 with later amendments), 
4. The Act of 28 August 1997 on the Organisation and Operation of Pension Funds (Journal of laws of 2013, no. 0, item 989),

5. The Act of 19 December 2008 on the Old-Age Bridging Pensions (Journal of laws of 2008, no. 237, item 1656 with later amendments),

6. The Act of 19 December 2008 on the Old-Age Bridging Pensions (Journal of laws of 2008, no. 237, item 1656 with later amendments),

7. The Act of 25 June 1999 on Social Security Cash Benefits in the Event of Sickness and Maternity (Journal of laws of 2010, no. 77, item 512 with later amendments),

8. The Act of 30 October 2002 on the Social Security in the event of Occupational Accident or Disease (Journal of laws of 2009, no. 167, item 1322 with later amendments),

9. The Act of 28 November 2003 on Family Benefits (Journal of laws of 2006, no. 139, item 992 with later amendments),

10. The Act of 27 June 2003 on the Social Pension (Journal of laws of 2013, no. 0, item 982),

11. The Act of 30 April 2004 on the Pre-Retirement Benefits (Journal of laws of 2013, no. 0, item 170),

12. The Act of 20 December 1990 on Farmers' Social Insurance (Journal of laws of 2008, no. 50, item 291 with later amendments),

13. The Act of 27 August 2004 on Health Care Services Financed from Public Funds (Journal of laws of 2008, no. 164, item 1027 with later amendments),

14. The Act of 20 August 2004 on Promotion of Employment and on Labour Market Institutions (Journal of laws of 2013, item 674),

15. The Act of 12 March 2004 on Social Assistance (Journal of laws of 2013, no. 0, item 182),

16. The Act of 28 November 2003 on Family Benefits (Journal of laws of 2006, no. 139, item 992 with later amendments),

17. The Act of 07 September August 2007 on Assistance to Persons Entitled to Alimony (Journal of laws of 2012, no. 0, item 1228),

18. The Act of 27 August 1997 on Professional and Social Rehabilitation and Employment of Disabled Persons (Journal of laws of 2011, no. 127, item 721).

It must be noted that since the moment of Poland's joining the European Union, the EU legal acts have become additional binding legal norms. 
Social insurance is the most essential and most frequently cited in media element of the social security system in Poland. There are two insurance systems in Poland: the common insurance system - managed by the Social Insurance Institution (Zakład Ubezpieczeń Społecznych - ZUS) and the Agricultural Social Insurance Fund (Kasa Rolniczego Ubezpieczenia Społecznego - KRUS) that services farmers. Other solutions applied can be referred to as the developments of the common system ${ }^{5}$.

Since 1999 a capital system has been operational in Poland under which the value of pensions is to be dependent on the value of the accumulated contributions ${ }^{6}$. However, every person that gains the right to receive the retirement benefit and during the period of his/her occupational activity does not accumulate the amount sufficient to receive a minimum pension will still hold the right to a minimum benefit guaranteed by the state Treasury (Owczarek, Więckowska 2011).

Farmers pay lower social insurance contributions than persons belonging to the common insurance system. Farmers receive small benefits that are only to a small degree dependent on the value of accumulated contributions (as a matter of fact they are dependent on the number of years during which one belonged to the system). A retired person that paid contributions for the period of 40 years is entitled to a benefit which is only $7 \%$ higher than the benefit received by a person who paid contributions for the period of 25 years (Walczak 2008).

The manifestation of solidarism within the old-age pension insurance system in Poland is the institution of family/widow's or widower's allowances which is paid to a deceased person's family, providing that person at the date of his/her death received (or was entitled to) old-aged pension or disability pension. A child is entitled to family allowances until a child is 16 or until he/she leaves education but only until he/she turns 25 years old. Widows are entitled to such allowances when they turn 50 years old.

${ }^{5}$ For instance, employees of uniformed services do not pay social insurance contributions and receive old-age pensions calculated based on the number of years worked and the average salary (in 2012 the retirement regulations concerning employees of uniformed services were changed by increasing the required length of service and modifying the rules of the calculation of the basis of the benefit), judges and prosecutors who finish their professional activity are granted the so-called 'the non-active status'.

${ }^{6}$ No matter whether social benefits will be serviced by state or private companies (however, there are some plans to implement changes in the functioning of these companies - Open Pension Funds), the essence of the further functioning of the capital system is unquestionable. 
In the scope of health insurance realised by the National Health Fund (Narodowy Fundusz Zdrowia - NFZ), every person that pays contributions (or is entitled otherwise) is entitled to free health services. In practice, every Polish citizen is entitled to health services: persons employed, persons running businesses and farmers are entitled to health services due to payment of contributions. Their family members may be registered for health insurances by the person insured. Unemployed persons are registered for insurance by a district labour office, and once they are registered they have the right to register other family members. Employees of uniformed services (the group includes the following: military, police, the Internal Security Agency, the Central Anti-Corruption Bureau) are entitled to health services and are not obliged to pay any contributions. This privilege is also shared by judges, prosecutors, and members of parliament.

The social security system in Poland is extensive and persons being in a difficult situation may count on various benefits including material (such as, for instance, health insurance contributions, social insurance contributions, accommodation, meals, clothes) and cash benefits (such as, for instance, regular benefit, temporary benefit, an allowance for an expense and for special expenses, an allowance and a loan for gaining financial independence, an allowance for gaining financial independence and continuation of education). Social assistance can be granted not only in case of financial problems. Pursuant to the act on social assistance, social assistance may be provided in respect of orphanage, unemployment, disability, prolonged or serious illness, family violence, difficulties with adaptation to life after leaving prison, random events and a crisis situation, natural or ecological calamities.

To sum up, it must be emphasized that a few hundred billion PLN is spent in Poland on financing social security (or only a few of its essential elements). Table one presents selected spending on social security. In accordance with the principle of solidarism, these costs are shared by all citizens for the benefit of needing ones (if beneficiaries of earlier retirement representing various professions may be named so - for instance, policemen). The report prepared for 2009-2013 specifies the following amounts:

1. Subsidy to the Social Insurance Fund (the basic and the only one in the common system) amounts to over 30 billion PLN and the overall costs are increasing dynamically, 
2. Subsidy to the Farmers' Pension and Disability Fund (the basic and major fund in the agricultural system) is slightly modified on an annual basis and amounts to approximately 15 billion PLN.

The costs of health services borne by the National Health Fund (financed by all that pay health insurance contributions) in 2012 amounted to 60.8 billion PLN and were 13 billion higher than in 2008. The spending of the State Fund for Rehabilitation of Disabled Persons (Państwowy Fundusz Rehabilitacji Osób Niepełnosprawnych - PFRON) oscillates around 4.2-4.8 billion PLN (as shown by the Report for 2009-2013). The spending on social assistance made by Polish regional authorities in 2012 was 12.7 billion PLN and it was the second largest spending after education. This spending exceeds several times the spending on, for instance, physical culture (in 2012 it was 2.4 billion PLN) (Information 2009-2013).

Table 1. Selected spending on social security in Poland in 2008-2012 (in billions of PLN)

\begin{tabular}{|l|l|c|c|c|c|c|}
\hline \hline & & 2008 & 2009 & $\mathbf{2 0 1 0}$ & $\mathbf{2 0 1 1}$ & $\mathbf{2 0 1 2}$ \\
\hline \hline \multirow{2}{*}{ Social insurance } & Social Insurance Fund (SIF) spending & 132.3 & 148.1 & 157.0 & 162.9 & 171.1 \\
\cline { 2 - 6 } & Subsidies for SIF from the state budget & 33.2 & 30.5 & 38.1 & 37.5 & 38.5 \\
\cline { 2 - 6 } & $\begin{array}{l}\text { Farmers' Pension and Disability Fund } \\
\text { (FPDF) spending }\end{array}$ & 16.8 & 17.0 & 16.5 & 16.5 & 17.1 \\
\cline { 2 - 6 } & $\begin{array}{l}\text { Subsidies for FPDF from the state } \\
\text { budget }\end{array}$ & 14.9 & 15.7 & 14.9 & 15.1 & 15.5 \\
\hline Health insurance & $\begin{array}{l}\text { Costs of the realisation of tasks by the } \\
\text { National Health Fund }\end{array}$ & 47.4 & 57.3 & 58.9 & 60.2 & 60.8 \\
\hline Fighting unemployment & The Labour Fund** & 5.5 & 10.9 & 11.7 & 8.6 & 9.4 \\
\hline $\begin{array}{l}\text { Rehabilitation } \\
\text { of disabled persons }\end{array}$ & $\begin{array}{l}\text { Current spending the State Fund for } \\
\text { Rehabilitation of Disabled Persons** }\end{array}$ & 4.7 & 4.5 & 4.3 & 4.2 & 4.8 \\
\hline Social assistance & $\begin{array}{l}\text { Spending of communes on social } \\
\text { assistance }\end{array}$ & 10.9 & 11.0 & 12.7 & 12.4 & 12.7 \\
\hline \hline
\end{tabular}

\footnotetext{
* The costs of the realisation of the tasks of the National Health Fund are covered by ZUS and KRUS.

** The Labour Fund is a state target fund that is to promote employment. Financial means disposed by the fund originate from contributions paid by self-employed persons.

${ }_{* * *}$ The State Fund for Rehabilitation of Disabled Persons spending is financed in $80 \%$ by compulsory contributions paid by companies.
}

S o u r c e : compiled by the author based on the Reports 2009-2013 and Information 2009-2013.

Total public expenditure on social security in Poland (covering expenditure on old age, survivors, incapacity related, health, family, active labour market 
programmes, unemployment, housing, and other), expressed in fixed prices in 2000 amounted to 86,929.40 million PLN in 1990, 146,734.80 million PLN in 1995, 173,157.30 million PLN in 2000 to 206,727.60 PLN million in 2005, and to $256,441.20$ million PLN in 2009. Since 2000, the expenditure in relation to GDP has been maintained at about $21 \%$ (20.94\% in 2013). The level of expenditure in relation to GDP in Poland is similar to the relationship in Hungary (in 2013, $21.56 \%$ of GDP), Ireland (in 2013, 21.59\% of GDP) and the Czech Republic (in $2013,21.77 \%$ of GDP). The size of the spending on social security and its share in GDP depend not only on the policy accepted for that matter and regulating the scope of services financed from public funds, but also on the financial situation of the country concerned. In Europe in 2013, the highest share of expenditure for social security in GDP was recorded in France (33.02\%), Denmark (30.79\%), Belgium (30.73\%) and in Finland (30.53\%) (OECD.StatExtracts).

Due to the demographic situation, expenditure on social security will certainly be increasing. In 1990, in the then European Union, merely $13.7 \%$ of the population was 65 or more, while, according to the latest forecasts, in 2035 the share of such persons (in 27 Member States) will be already 25.2\%. In Poland, this share will also increase from about 11.2 to 23.2\% (Demography Report 2010, 66; Prognoza ludności...).

Moreover, despite a general antipathy shown to institutions dealing with the realization of inter-generation solidarism and securing socially the weakest (ZUS, KRUS, NFZ), the opinion that the state should provide its citizens with basic life needs is very common (CBOS 2013). This expectation of the state's role can be ascribed to the heritage of communism; the years 1945-1990 in Poland were the years of a continuous extension of the scope of obligations of the republic of working people, as it was defined by the then Constitution.

\section{CONCLUSIONS RESULTING FROM THE RESEARCH PROCESS}

It may be stated that Poland realises the ideas of social solidarism through various elements of social security. Poland has operational systems in the areas of social insurance, health services, social assistance, or supporting unemployed persons. The system of social security is still being expanded. For years the number of social benefits offered has increased and their scope has been adjusted to citizens' expectations as well as to the ideas of social solidarism originating also from the teachings of the Catholic Church. 
Therefore, it seems that the social teaching of the Catholic Church concerning social and economic issues are accepted by the majority of the Polish society regardless of their religious views. However, a concern is the dissonance between the scale of the state's obligations to citizens, as indicated by CBOS respondents, and the scale of obligations on the side of citizens. Expecting form the community (on the levels of the country and local authorities) to play a significant role in providing social security does not contradict the teachings of the Catholic Church, which, in accordance with the principle of subsidiarity, objects to the state's usurping too many rights in that respect.

The factors presented in the work that influence the scope and the value of benefits in social security are important in the face of an aging population. These factors, which include history, culture, or religion, will affect an increasingly better financial security of the growing number of retirees, generating thereby the increasing budgetary expenditure.

\section{REFERENCES}

Aspalter Ch., Jinsoo K., Sojeung P. (2009), Analysing the Welfare State in Poland, the Czech Republic, Hungary and Slovenia: An Ideal-Typical Perspective, "Social Policy\& Administration", vol. 43, no. 2, 170-185. DOI: 10.1111/j.1467-9515.2009.00654.x.

Backer L. C. (2010), Values Economic, Theology and Legitimacy: Catholic Social Thought and Its Implications for Legal Regulatory Systems, "Economics, Management, and Financial Markets", vol. 5, no. 2, 17-56.

CBOS (2013), Komunikat z badań Powinności państwa wobec obywatela i obywatela wobec państwa, http://www.cbos.pl/SPISKOM.POL/2013/K_104_13.PDF (access: 3.10.2013).

Chojnicka K. (2001), Nauka społeczna Kościoła katolickiego (zarys historii), Collegium Columbinum Kraków.

Demography Report 2010 Older, more numerous and diverse Europeans (2011), COMMISSION STAFF WORKING DOCUMENT, European Commission, Luxembourg.

Fajth G. (1999), Social Security in a Rapidly Changing Environment: The Case of the Post-communist Transformation, "Social Policy \& Administration", vol. 33, no. 4, 416-436. DOI: 10.1111/1467-9515.00161.

Garbiec R. (2008), Zabezpieczenie społeczne. Istota i elementy systemu, Wyd. Politechniki Częstochowskiej, Częstochowa.

Informacja o wykonaniu budżetów jednostek samorządu terytorialnego $w$ latach 2008-2012 r., Ministerstwo Finansów, Warszawa 2009-2013.

Koczur W. (2012), Zabezpieczenie społeczne. Zarys problematyki, Wyd. UE w Katowicach, Katowice.

Łyskawa K. (1999), Dochody osób w starszym wieku a zarządzanie ryzykiem starości, „Ruch Prawniczy, Ekonomiczny i Socjologiczny”, nr 1, 183-198. 
OECD.StatExtracts, http://stats.oecd.org/Index.aspx?DataSetCode=SOCX_AGG (access: 6.12.2013).

Owczarek J., \& Więckowska B. (2011), Ryzyko dopłaty do emerytury minimalnej w nowym systemie emerytalnym $w$ Polsce, „Zeszyty Naukowe Uniwersytetu Ekonomicznego w Poznaniu", nr 181, 331-340.

Pelczar J. S. (1915), Zarys dziejów miłosierdzia w Kościele katolickim, Przemyśl.

Plan finansowy Narodowego Funduszu Zdrowia na lata 2008-2012, Narodowy Fundusz Zdrowia, Warszawa.

Prognoza ludności na lata 2008-2035, Baza Demograficzna GUS, http://demografia.stat. gov.pl/bazademografia (access: 10.10.2013).

Rugina A. N. (1983), About the Doctrine of "Solidarism" in Social Economics, "International Journal of Social Economics", vol. 10, no. 2, 62-71.

Social Security Programs Throughout the World: Europe (2012), "SSA Publication”, no. 13, 11801.

Sprawozdania z wykonania budżetu państwa w latach 2008-2012 r., Ministerstwo Finansów, Warszawa 2009-2013.

Strzeszewski C. (1994), Katolicka nauka społeczna, Lublin.

Strzeszewski C. (1960), Bona superflua w etyce społecznej św. Tomasza z Akwinu, „Roczniki Filozoficzne, t. 8, z. 2, 53-59.

Ustawa z dnia 12 marca 2004 r. o pomocy społecznej, Dz.U. 2013, nr 0, poz. 182.

Ustawa z dnia 4 września 1997 r. o działach administracji rządowej, Dz.U. 2013, nr 0, poz. 743 .

Walczak D. (2008), Kierunki zmian ubezpieczeń społecznych rolników, „Prace Naukowe Akademii Ekonomicznej we Wrocławiu", nr 1197, 444-449.

Walczak, D. (2011), Uwarunkowania funkcjonowania systemu zabezpieczenia społecznego rolników w Polsce, TNOiK, Toruń, 20-41.

Wyszyński S. (1959), List do kardynała Dominico Tardiniego. 23 września 1959, „Acta et documenta Concilio Oecumenico Vaticano II Apparando", series II, vol. II, pars II, 679-685.

Zieliński T. (1994), Ubezpieczenia społeczne pracowników, Wyd. Naukowe PWN, Warszawa. 